\title{
Report on the effectiveness of vegetative barriers to regulate simulated fluxes of runoff and sediment in open agricultural landscapes (Flanders, Belgium)
}

\author{
Amaury Frank $\mathbf{l}^{1,2}$ @ | Maarten De Boever ${ }^{3,4}$ | Jonas Bodyn ${ }^{4}$ | Saskia Buysens ${ }^{4}$ | \\ Liesbet Rosseel $^{5}$ | Sarah Deprez $^{5}$ | Charles Bielders ${ }^{6}$ (i) | Aurore Dégre ${ }^{7}$ ( ) | \\ Alexia Stokes ${ }^{2}$ ()
}

${ }^{1}$ Department of Geography, Ghent University, Ghent, Belgium

${ }^{2}$ INRAE, AMAP, IRD, CIRAD, CNRS, University Montpellier, Montpellier, France

${ }^{3}$ Research Institute for Agriculture, Fisheries and Food (ILVO), Merelbeke, Belgium

${ }^{4}$ PCG - Vegetable Research Centre, Kruishoutem, Belgium

${ }^{5}$ Steunpunt Erosie, Provinciaal Centrum voor Milieuonderzoek, Ghent, Belgium

${ }^{6}$ Earth and Life Institute, Environmental Sciences, Université catholique de Louvain, Louvain-la-Neuve, Belgium

${ }^{7}$ Terra Research Centre, Gembloux Agro-Bio Tech, Liege University, Liège, Belgium

\section{Correspondence}

Amaury Frankl, Department of Geography, Ghent University, Ghent, Belgium.

Email: amaury.frankl@ugent.be

Funding information

Triple C project: Climate resilient communitybased catchment planning and management; Interreg 2 Seas project

\begin{abstract}
Vegetative barriers are increasingly used to reduce sediment export from cropland and thus mitigate negative off-site consequences of soil erosion. Here, we report and discuss the effectiveness of vegetative barriers implemented in Flanders (Belgium) to buffer the flows of water and sediment. The three types of vegetative barriers studied are made of straw bales, wood chips or bales of coconut- fibre. Based on three simulated runoff experiments performed in the field, we calculated the hydraulic roughness and sediment deposition ratio. Our experiments showed that the barriers made of coconut-fibre bales performed markedly better than those of straw bales or wood chips (Manning's $n$ values of $1.355,1.049$ and $2.231 \mathrm{~s} \mathrm{~m}^{-1 / 3}$ and a sediment deposition ratio of $19 \%, 38 \%$ and $64 \%$ for barriers made of straw bales, wood chips and coconut-fibre bales, respectively, during the first experiment). These values increased during subsequent experiments demonstrating the effect of sediment accumulating inside the structures. Especially for coconut-fibre bales, this accumulation increases the risk of runoff bypassing or overtopping the barriers. The barriers mainly retained sand and, to a lesser extent, silt and clay. As vegetative barriers have to be renewed every few years because of the decomposition of organic material, barriers made of locally available materials are more sustainable as a nature-based solution to erosion. We conclude that although the vegetative barriers made of coconut-fibre bales are superior in their regulation of flows of runoff and sediment, barriers made of locally sourced materials are more sustainable.

KEYWORDS

agriculture, erosion control, hydrological connectivity, runoff, sediment
\end{abstract}

\section{1 | INTRODUCTION}

Accelerated soil erosion is a serious threat to sustainable development worldwide, as it impairs the invaluable ecosystem services provided by healthy soils (Keesstra et al., 2016). Specific to intensively cultivated areas in rolling topographies is the issue of hydrological and sediment connectivity of the land (Bracken \& Croke, 2007). During the scaling up of agricultural practices, intensive farming systems have often created open landscapes, largely depleted of perennial vegetation, in which runoff can move largely unhindered. As a result, many headwaters that are intensively farmed suffer from flooding, and downslope, rivers are exposed to 
pollution from sediment, nutrients and pesticides (Verstraeten \& Poesen, 2002). When the connectivity of the land is high, off-site problems may persist even if erosion rates are within acceptable margins (Boardman et al., 2019).

To reduce sediment export from cropland, farmers and land managers are increasingly implementing small-scale measures such as vegetative barriers. The latter are small permeable dams made of narrow strips of stiff, dense vegetation or barriers made of vegetal biomass (Frankl et al., 2021). These barriers can be implemented at the lower edge of erosion-prone fields or, more ideally, across concentrated flow zones. By increasing the hydraulic roughness across the flow zone, vegetative barriers reduce the runoff velocity and, in consequence, cause runoff to accumulate and spread upslope (Kervroëdan et al., 2021). As a result of the decrease in the transport capacity of the flow, sedimentation occurs, both in the ponding water and inside the vegetative barrier. In addition, vegetative barriers protect locally from erosion and can strongly increase infiltration, especially where plant roots develop (Frankl et al., 2018; Kervroëdan et al., 2021; Richet et al., 2017).

Even though vegetative barriers are increasingly implemented in agricultural land, few data exist on their hydraulic roughness or sediment deposition rate. In NW Europe, however, several studies have been devoted to understanding their hydro-geomorphological effects (e.g., Vander Linden, 2011; Ouvry et al., 2012; Degré \& Bielders, 2016; Richet et al., 2017; Frankl et al., 2018; Kervroëdan et al., 2018; Boardman et al., 2019). Here, we report on the hydraulic resistance and sediment deposition ratio (SDR) of vegetative barriers that have recently been implemented in the agricultural areas of Flanders (Belgium). These barriers have been co-designed by local farmers and stakeholders and are largely unique to the area in terms of the vegetative materials used. As such, we want to improve the transfer of knowledge between agricultural regions and discuss the potential of vegetative barriers for reducing sediment export. This demonstration is important for communicating to farmers the advantages of adopting such measures and for modelling sediment transport to support land management policies (Frankl et al., 2018).

\section{2 | METHODS}

\section{1 | Experimental field site}

The vegetative barriers investigated were made of (i) straw bales (width $=0.45 \mathrm{~m}$, density $73 \mathrm{~kg} \mathrm{~m}^{-3}$, Figure 1a), (ii) wood chips (width $=0.92 \mathrm{~m}$, density $520 \mathrm{~kg} \mathrm{~m}^{-3}$, Figure $1 \mathrm{~b}$ ), and (iii) bales of coconut-fibre (width $=0.40 \mathrm{~m}$, density $143 \mathrm{~kg} \mathrm{~m}^{-3}$, Figure 1c). The experimental field site where the vegetative barriers were studied was located near the village of Nukerke in East Flanders, Belgium $\left(50.7741^{\circ} \mathrm{N}, 3.5877^{\circ} \mathrm{E} ; 89 \mathrm{~m}\right.$ a.s.I.). The mean annual precipitation and temperature are within the range of $900-1000 \mathrm{~mm}$ and $10-10.5^{\circ} \mathrm{C}$, respectively (RMI, 2021). The soil texture is sandy loam, and according to the World Reference Base for Soil Resources, the soil is a Haplic Luvisol (Dondeyne et al., 2014). The barriers of straw and coconutfibre were placed in the field about 2 months before the experiment. A wood-chip barrier was placed 1.5 years earlier. Since runoff from the upper slope is diverted away from the vegetative barriers, it did not accumulate sediment prior to the experiments, and the settled barriers were considered as new structures, which had the time to settle at their base.
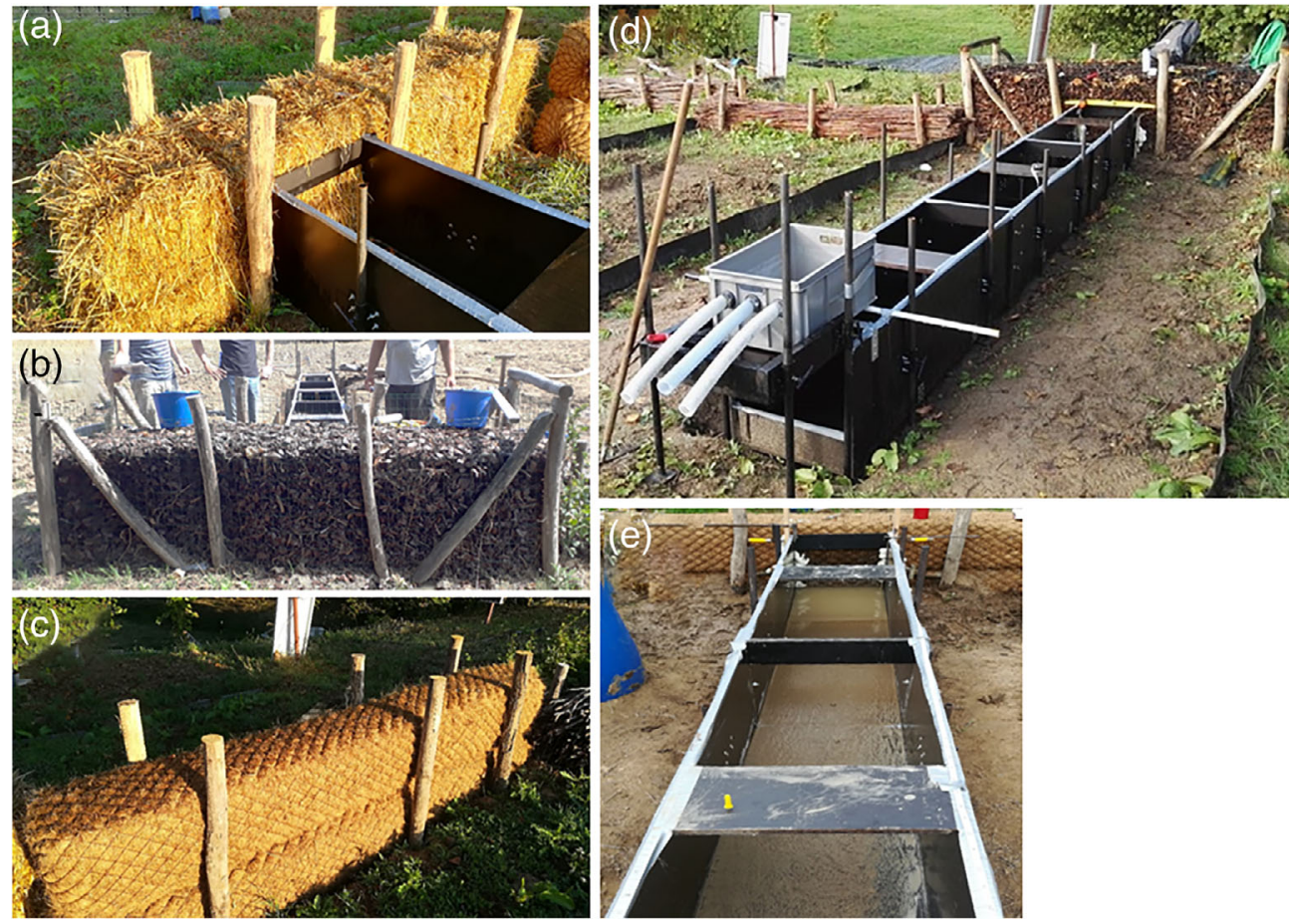

FIGURE 1 Types of vegetative barriers studied: (a) straw bales; (b) wood-chips; (c) coconut-fibre bales and (d) experimental setup to simulate sediment-laden runoff events, also showing the flume fitted to the barrier and the earth dam ponds at each side of the flume. (e) Sediment deposited in the flume after an experiment, also showing ponded water [Colour figure can be viewed at wileyonlinelibrary.com] 


\section{2 | Determining the hydraulic roughness and sediment deposition ratio from simulated runoff events}

For each type of vegetative barrier, the runoff events were simulated three times on the same barrier on 17 and 18 August 2020. Therefore, we constructed a rectangular flume based on the design of Ouvry et al. (2012). This flume consists of a channel $6 \mathrm{~m}$ long $\times 0.5 \mathrm{~m}$ wide $\times 0.5 \mathrm{~m}$ deep. The flume was installed at the upslope front of the vegetative barriers, perpendicular to their longitudinal axis (Figure 1d,e). The slope of the flume was set at $9 \%$ ( local slope gradient) using a clinometer and by adjusting the adjustable metal support legs. At the upper side of the flume, a perforated plastic storage box was placed that allowed to feed the flume with a flow of water and topsoil. We close-fitted the flume to the barriers and filled any gaps around the flume edges with expanding foam to avoid leakage. To ensure that the runoff did not divert sideways inside the vegetative barriers, we made small earth dam ponds on each side of the flume and filled them with water during the experiments. As such, the flume (together with the two small ponds) functioned as a double-ring infiltrometer. A ruler was placed vertically in the flume at its contact with the vegetative barriers in order to record the water level height (at $\mathrm{cm}$ resolution).

We aimed at simulating runoff events similar to those performed in previous studies (e.g., Degré \& Bielders, 2016; Richet et al., 2017), while also considering the feasibility of such experiments under field conditions. For the sediment discharge, this means that we simulated a rather low sediment concentration as compared to what can be expected in field conditions. Fields unprotected by vegetation may produce runoff with sediment concentrations reaching approximately $200 \mathrm{~g} \mathrm{~L}^{-1}$ (Steegen et al., 2000). However, Degré and Bielders (2016) showed that sediment deposition in the flume is mainly influenced by slowing down the flow rate and building up backwater - which in turn depends on the characteristics of vegetative barriers influencing the water level height - and not by the sediment load of the flow. Our results can therefore provide valuable information on the effectiveness of vegetation barriers.

To ensure a constant water discharge during the simulated runoff experiments, the pressure by the water column in the perforated box was kept constant to the level of three evacuation holes (connected to tubes) at the back of the box. The resulting discharge simulation was $9.1 \pm 0.3 \mathrm{~L} \mathrm{~s}^{-1} \mathrm{~m}^{-1}$ ( peak flow rate in small catchments in NW Europe; Ouvry et al., 2012; Degré \& Bielders, 2016) as determined by recording the time it takes to fill a container of $200 \mathrm{~L}$, repeated threetimes. To simulate a sediment discharge, the topsoil collected before the tests from the field site was sieved at $2 \mathrm{~mm}$ and air-dried. To achieve a constant flow of sediment, the topsoil was first inserted into two buckets of water and mixed manually while feeding it into the box at a constant speed. The resulting simulated sediment concentration was $5.5 \pm 0.3 \mathrm{~g} \mathrm{~L}^{-1}$.

When the flume was in place, we first tested the experimental set-up and only started measuring once we observed that no leakage occurred between the flume and the barrier. The simulated runoff experiment then consisted of three phases: (1) feeding the flume with a constant discharge and measuring the water level height at its contact with the vegetative barriers once the water level was stable for approximately $15 \mathrm{~s}\left(t_{1}=0\right.$, Table 1$)$. This water level was used to calculate the Manning $n$ coefficient (see below). (2) Keeping the discharge constant and feeding the flume with sediment for $60 \mathrm{~s}$, and then measuring the water level after $t_{2}=30 \mathrm{~s}$ and $t_{3}=60 \mathrm{~s}$. (3) Stopping the discharge and collecting the sediment deposited in the flume.

To define the hydraulic resistance, we used the empirical Manning $n$ coefficient, to be consistent with previous research on vegetative barriers (Ouvry et al., 2012; Degré \& Bielders, 2016; Richet et al., 2017; Kervroëdan et al., 2018). Manning's $n$ is also used as an input parameter to numerous hydrological models (e.g., LISEM and WATEM-SEDEM). Strictly speaking, defining Manning's $n$ requires steady flow and a constant water level in the flow section (i.e., inside the barrier). As this condition is not fulfilled, the Manning $n$ values presented here are an approximation of the hydraulic roughness, as also discussed in Richet et al. (2017). Manning's $n$ is determined using Equation (1):

$$
n=\frac{1}{Q} A R^{2 / 3} S^{1 / 2}
$$

Where: $n$ is the Manning's roughness coefficient in $\mathrm{s} \mathrm{m}^{-1 / 3} . Q$ is the flow rate in $\mathrm{m}^{3} \mathrm{~s}^{-1}$. $A$ is the cross-sectional area of flow in $\mathrm{m}^{2}$ (or $A=L^{*} h, L$ is the channel width and $h$ the height of the flow at the vegetation barrier, measured at the same location during every experiment). $R$ is the hydraulic radius in $m$ (or $R=A / P, P$ being the wetted perimeter). $S$ is the slope of the flume in $\mathrm{m} \mathrm{m}^{-1}$.

The SDR is the ratio of the sediment deposited in the flume to the sediment injected in the flume. The grain size distribution was determined after dry sieving following standard procedures and classed into fractions (sieve openings, see Table 1).

\section{3 | RESULTS AND DISCUSSION}

The buffering of the water flow was most pronounced for barriers made of bales of coconut fibre, and this caused the water level in the flume to increase most and thus also produce the highest hydraulic roughness (Table 1 ). It also took $>1 \mathrm{hr}$ before the flume fully emptied at the coconut-fibre barriers. This time lag has a significant effect on the reduction of the hydrological connectivity. However, the high hydraulic roughness also increases the risk of runoff bypassing or overflowing the barriers, especially once the barriers are clogged with sediment and cause a marked increase of the water level during subsequent runoff events (Table 1). The barriers made of straw bales or wood-chips produced a lower hydraulic roughness (and also emptied rapidly after the simulated runoff events). The increase in the water level during subsequent runoff events was also less pronounced so that the barriers made of straw bales or wood--chips remain functional over longer periods as compared to the barriers made of coconut-fibre bales. Such effects have to be considered by both land managers and modellers. For the latter, the Manning $n$ values at $t_{1}$ of 


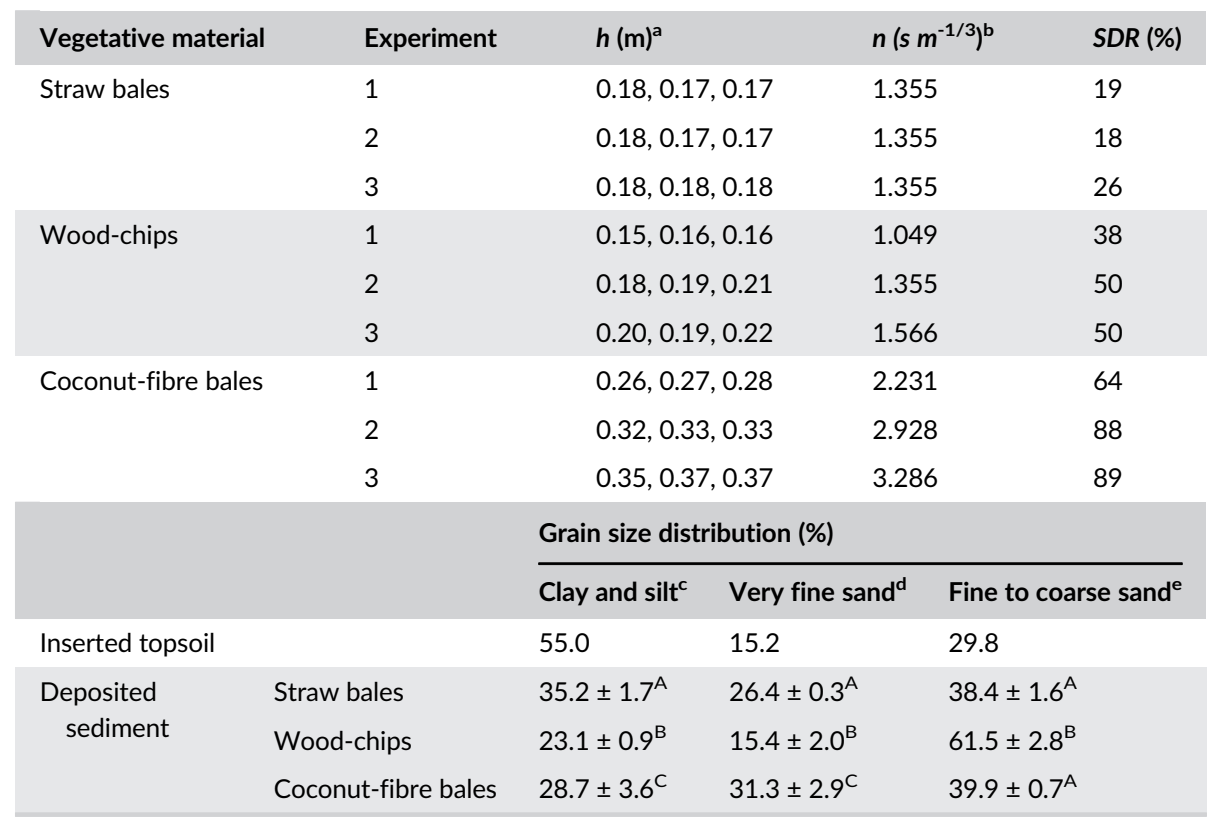

TABLE 1 Effectiveness of the vegetative barriers: steady-state water height $(h)$, hydraulic roughness (Manning's $n$ ), sediment deposition ratio $(S D R)$ and grain size distribution of inserted and deposited sediment

Note: A, B, C show statistical difference from the ANOVA LSD test at $\alpha=0.05$

${ }^{\text {a At }} t_{1}, t_{2}, t_{3}$

${ }^{\mathrm{b}}$ At $t_{1}$

${ }^{c}<0.064 \mathrm{~mm}$

d0.064-0.125 mm

e $0.125-2 \mathrm{~mm}$

the first experiment (i.e., newly implemented barriers) are most suited to compare between studies, or $1.355,1.049$ and $2.231 \mathrm{~s} \mathrm{~m}^{-1 / 3}$, respectively, for the barriers made of straw bales, wood-chips and coconut-fibre bales. These values will however increase once the barriers fill with sediment.

For the sediment deposition ratio, the barriers made of coconutfibre bales trapped most sediment (Table 1). For the first experiment, the deposition ratio was $19 \%, 38 \%$ and $64 \%$, respectively, for the barriers made of straw bales, wood chips and coconut-fibre bales. For all types of barriers, there was a positive effect of the increase in the water level (due to sediment accumulation inside the barriers during subsequent experiments) on the SDR (Figure 2). Remarkably, the barriers made of coconut-fibre bales could retain almost all the inserted sediment after the first experiment. The increase in the SDR did, however, not change the barrier's efficiency in trapping fine sediments. Subsequent tests did not change the grain size distribution much and the variability remained very small (Table 1 ). The barriers were most effective in trapping sand. Therefore, we could not explain sediment grain size distribution by the SDR as carried out in the study by Richet et al. (2017). Overall, the results of Table 1 are within the range of previous studies in NW Europe (e.g., Vander Linden, 2011; Ouvry et al., 2012; Degré \& Bielders, 2016; Richet et al., 2017; Kervroëdan et al., 2018), even though these studies mainly considered other types of vegetative barriers (e.g., made of brushwood fences or live vegetation). Improving the efficiency of the barriers in trapping fine sediments could be achieved by implementing grass strips downslope of the barriers, where gently flowing water spreads over the slope below

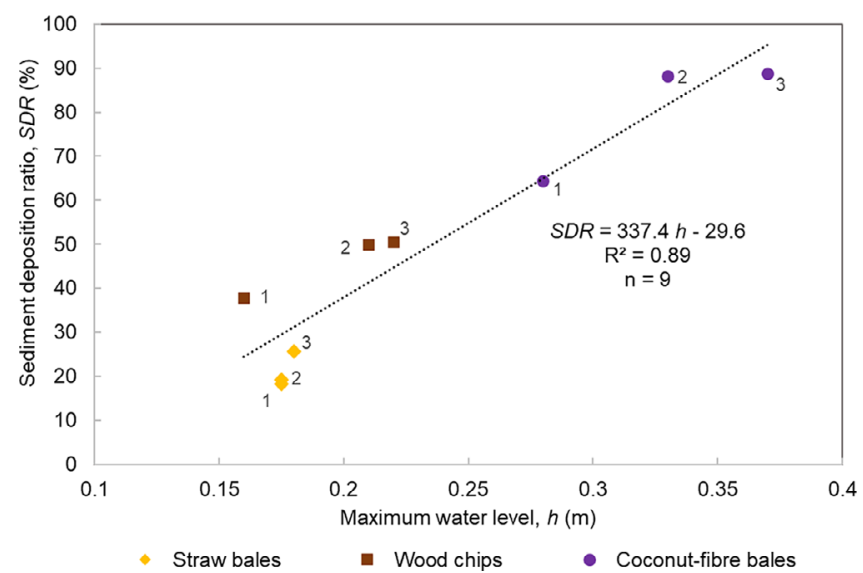

FIGURE 2 Relationship between maximum water level and sediment deposition ratio for subsequent simulated runoff events (after experiments 1, 2 and 3, Table 1) indicating that as the barriers fill with sediment, they become more effective in trapping sediment [Colour figure can be viewed at wileyonlinelibrary.com]

the barrier. A gentle flow of water inside a grass strip could also improve infiltration rates and therefore reduce the risks of ephemeral gully erosion by the clear water effect (Frankl et al., 2018).

In terms of sustainability, using locally sourced materials is preferable as the vegetative barriers have to be renewed regularly. In that regard, using coconut fibre is less sustainable as it is not locally available in NW Europe. Straw and wood chips can be locally sourced. 
Straw is readily available as an agricultural by-product. Wood chips can be produced following the trimming of local hedges and trees. Furthermore, wood chip barriers can fulfil other services such as providing shelter for insects (such as an insect hotel) or increase infiltration rates as a well-textured soil, rich in organic matter, develops below them.

\section{4 | CONCLUSIONS}

Vegetative barriers are increasingly used in agricultural regions as a nature-based solution to land degradation. Largely unique to the region in terms of materials used, the barriers made of straw bales, wood chips and coconut-fibre bales were shown to have a major effect on buffering flows of water and sediment, the most effective being bales made of coconut fibre. The latter, however, rapidly fill with sediment and therefore increase the risks of runoff bypassing or overtopping during subsequent events. In addition, coconut fibre is imported, therefore, we suggest using vegetative barriers made from locally sourced vegetative materials such as straw or woodchips.

\section{ACKNOWLEDGEMENTS}

This research was partly funded by the Interreg 2 Seas project Triple $C$ project: Climate resilient community-based catchment planning and management.

\section{DATA AVAILABILITY STATEMENT}

The data that support the findings of this study are available from the corresponding author upon reasonable request.

\section{ORCID}

Amaury Frankl (D) https://orcid.org/0000-0002-1685-2780

Charles Bielders (D) https://orcid.org/0000-0003-2865-4236

Aurore Dégre (D) https://orcid.org/0000-0001-6912-6136

Alexia Stokes (D) https://orcid.org/0000-0002-2276-0911

\section{REFERENCES}

Boardman, J., Vandaele, K., Evans, R., \& Foster, I. D. L. (2019). Off-site impacts of soil erosion and runoff: Why connectivity is more important than erosion rates. Soil Use and Management, 35, 245-256. https:// doi.org/10.1111/sum.12496

Bracken, L. J., \& Croke, J. (2007). The concept of hydrological connectivity and its contribution to understanding runoff-dominated geomorphic systems. Hydrological Processes, 1763, 1749-1763. https://doi.org/10. 1002/hyp.6313

Degré, A., \& Bielders, C. (2016). GISER - Rapport 2016. Université de Liège, Gembloux Agrobiotech and Université catholique de Louvain. Jambes: Service Public de Wallonie.

Degré, A., \& Bielders, C. (2016). GISER - rapport 2016. In Université de Liège, Gembloux Agrobiotech and Université catholique de Louvain. Liege: Service Public de Wallonie.
Dondeyne, S., Vanierschot, L., Langohr, R., Van Ranst, E., \& Deckers, J. (2014). In The soil map of the Flemish region converted to the 3rd edition of the world reference base for soil resources. Brussels: Departement Leefmilieu, Natuur en Energie.

Frankl, A., Nyssen, J., Vanmaercke, M., \& Poesen, J. (2021). Gully prevention and control: Techniques, failures and impact. Earth Surface Processes and Landforms, 46, 220-238. https://doi.org/10.1002/esp.5033

Frankl, A., Prêtre, V., Nyssen, V., \& Salvador, P.-G. (2018). The success of recent land management efforts to reduce soil erosion in northern France. Geomorphology, 303, 84-93. https://doi.org/10.1016/j. geomorph.2017.11.018

Keesstra, S. D., Bouma, J., Wallinga, J., Tittonell, P., Smith, P., Cerdà, A., Montanarella, L., Quinton, J. N., Pachepsky, Y., van der Putten, W. H., Bardgett, R. D., Moolenaar, S., Mol, G., Jansen, B., \& Fresco, L. O. (2016). The significance of soils and soil science towards realization of the United Nations Sustainable Development Goals. The Soil, 2, 111128. https://doi.org/10.5194/soil-2-111-2016

Kervroëdan, L., Armand, R., \& Rey, F. (2021). Trait-based sediment retention and runoff control by herbaceous vegetation in agricultural catchments: A review. Land Degradation \& Development, 32, 1077-1089. https://doi.org/10.1002/ldr.3812

Kervroëdan, L., Armand, R., Saunier, M., Ouvry, J.-F., \& Faucon, M.-P. (2018). Plant functional trait effects on runoff to design herbaceous hedges for soil erosion control. Ecological Engineering, 118, 143-151. https://doi.org/10.1016/j.ecoleng.2018.04.024

Ouvry, J. F., Richet, J. B., Bricard, O., Lhériteau, M., Bouzid, M., \& Saunier, M. (2012). Fascines \& haies pour réduire les effets du ruissellement érosif: Caractérisation de l'efficacité et conditions d'utilisation. In Association Régionale pour l'Etude et l'Amélioration des Sols (AREAS). Franqueville-Saint-Pierre: Imprimerie Gabel.

Richet, J., Ouvry, J., \& Saunier, M. (2017). The role of vegetative barriers such as fascines and dense shrub hedges in catchment management to reduce runoff and erosion effects: Experimental evidence of efficiency, and conditions of use. Ecological Engineering, 103, 455-469. https://doi.org/10.1016/j.ecoleng.2016.08.008

RMI. (2021, May 6). Climate of Belgium, Royal Meteorological Institute of Belgium. Retrieved from https://www.meteo.be/nl/klimaat/klimaatvan-belgie/klimaatatlas.

Steegen, A., Govers, G., Nachtergaele, J., Takken, I., Beuselinck, L., \& Poesen, J. (2000). Sediment export by water from an agricultural catchment in the Loam Belt of Central Belgium. Geomorphology, 33, 25-36. https://doi.org/10.1016/S0169-555X(99)00108-7

Verstraeten, G., \& Poesen, J. (2002). Regional scale variability in sediment and nutrient delivery from small agricultural watersheds. Journal of Environmental Quality, 31, 870-879. https://doi.org/10.2134/jeq2002.8700

Vander, L. B. (2011). Evaluatie van kleinschalige erosiedammen in de Vlaamse Ardennen. MSc thesis Faculty of Bioscience Engineering, Ghent: Ghent University.

How to cite this article: Frankl, A., De Boever, M., Bodyn, J., Buysens, S., Rosseel, L., Deprez, S., Bielders, C., Dégre, A., \& Stokes, A. (2021). Report on the effectiveness of vegetative barriers to regulate simulated fluxes of runoff and sediment in open agricultural landscapes (Flanders, Belgium). Land Degradation \& Development, 32(15), 4445-4449. https://doi. org/10.1002/Idr.4048 